\title{
Pontificio Consiglio per la Famiglia, Famiglia e questioni etiche, Edizioni Dehoniane, Bologna 2004, ss. 592
}

Problematyka człowieka pozostaje na zawsze wiodącą we wszelkiej refleksji ludzkiej. Zapewne tak było od samych początków, gdy on pochylał się nad sobą samym. Jest to bowiem przecież zainteresowanie sobą samym, co wręcz wydaje się oczywistym i wpisanym $\mathrm{w}$ samą rozumną naturę człowieka, tak $\mathrm{w}$ jego znamionach indywidualnych, jak i wspólnotowych. To jednak nie egoizm, ale realizm odpowiedzialnego spoglądania na siebie samego oraz otaczający świat. Nie można bowiem pominąć odpowiedzialnego spojrzenia na człowieka, gdy analizuje się twórczo prawdę stworzenia.

Realność człowieka wskazuje wyraźnie, iż nie jest on sam, choć nie musi do końca tego sobie uświadamiać, czy snuć wokół tego zawiłych refleksji. Taki jest bowiem ze swej natury, co zauważali już starożytni myśliciele. W tej specyfice wspólnoty, społeczności czy komunii przede wszystkim staje rodzina, naturalna, najmniejsza wspólnota życia. Jawi się ona jako rzeczywistość niepowtarzalna, choć czasem kwestionowana, ale ostatecznie realna i wyraźnie wpisana w konstrukcje ludzkiego świata społecznego i wspólnotowego.

Oto Papieska Rada ds. Rodziny opublikowała obszerną publikację zbiorową poświęconą problematyce rodziny. Warto zatem pochylić się nad tą propozycją. Książkę otwiera wprowadzenie kard. A. Lopez Trujillo, wieloletniego i aktualnego przewodniczącego Papieskiej Rady ds. Rodziny (s. 5-8). Natomiast całość treściowa podzielona została na sześć obszernych i tematycznie zorganizowanych części.

Pierwsza część opatrzona została tytułem: „Małżeństwo, rodzina i miłość małżeńska” (s. 9-103). W jej ramach zamieszczono osiem specjalistycznych opracowań szczegółowych. Otwiera go tekst zatytułowany: „Doktrynalne fundamenty rodziny” pióra C. Caffara (s. 11-19). Z kolei dalszą refleksję ukazuje tekst: „Biskup i duszpasterstwo rodziny”, które przygotował A. Lopez Trujillo (s. 21-31). C. Caffar omówił także zagadnienie: „Małżeństwo i rodzina: doktryna Magisterium papieskiego w "Familiaris consortio"” (s. 33-42).

W ramach tej części wskazano na kwestie: „Małżeństwo i rodzina w kulturze życia", które omówił F. Gil Hellin (s. 43-51). Z kolei ukazano trudne zagadnienie: 
„Konfuzje uczuciowe i ideologiczne, które dotykają związki współczesne” opisane przez T. Anatrella (s. 53-66). Natomiast „Nowe wyzwania wobec rodziny i życia. Duszpasterstwo rodzin i małżeństw w trudnościach" ukazał A. Lopez Trujillo (s. 67-80). Następnie temat: „Ojcostwo i macierzyństwo odpowiedzialne” omówił F. Gil Hellin (s. 81-93). Kończąc tę część wskazano jeszcze temat: „Rodzina i jedność faktyczna. Analizy antropologiczne i etyczne" przedstawiony przez D. Tettamanzi (s. 95-103).

Kolejna część prezentowanego studium opatrzona została tytułem: „Rodzina i seksualność (s. 105-164). Otwiera ją artykuł pt. „Od wizji permisywnej do wizji naturalistycznej seksualności” przygotowany przez E. Sgreccia i M. Luisa Di Pietro (s. 107-126). Natomiast kwestię: „Rewolucja seksualna” ukazał P. J. Elliott (s. 127-140). Ten sam autor podniósł także zagadnienie: „Kościół katolicki i seksualność" (s. 141-153). Również jego autorstwa jest kolejne przemyślenie: „Jak wychowywać nasze dzieci do seksualności?” (s. 155-164).

„Rodzina i prokreacja” to ogólna tematyka trzeciej części prezentowanego opracowania (s. 165-271). Najpierw F. Gil Hellin wskazał na temat: „Miłość małżeńska, gwarancja służby życiu" (s. 167-176). Z kolei ukazano zagadnienie: „Rodzina, płodność i życie we współczesnej społeczności” zaprezentowane przez F. Di Felice (s. 177-182). Natomiast F. C. Fernandez podjął dość obszernie zagadnienie: „Rodzina i prokreacja” (s. 183-210). Temat: „Kontrola prokreacji ludzkiej: aktualność antykoncepcji i sterylizacji” omówił J. Suaudeau (s. 211-241). Pierwszy polski autor G. Kaszak przybliżył tematykę: „Podstawy nauczania Kościoła w problematyce antykoncepcji” (s. 243-251). Ostatni blok tej części koncentruje się wokół zagadnienia: „Zapłodnienie wspomagane. Aktualna panorama" przygotowanego przez F. C. Fernandez (s. 253-271).

Część czwarta prezentowanego zbioru koncentruje się wokół tematyki: „Rodzina i synowie” (s. 273-304). Najpierw ukazano tutaj temat: „Relacja miedzy darem małżeńskim i darem synów: generacje i edukacja”, który przygotował C. Caffara (s. 275-281). Z kolei T. Anatrella ukazał zagadnienie: „Uczucia i seksualność niepełnosprawnych” (s. 283-292). Dobrze się stało, że w końcu tej części wskazano na kwestię: „Rodzina i prawa mniejszych” opracowaną przez F. D`Agostino (s. 293-304).

Ważnym jest podjęcie w części piątej tematu: „Rodzina i społeczność” (s. 305-391). Analizę otwierają stwierdzenia wokół kwestii: „Rodzina, baza dla społeczności” opracowanej przez F. D`Agostino (s. 307-313). Problemowi: „Rodzina i etyka” pióra F. Di Felice poświęcono kolejne analizy tej części (s. 315-320). Natomiast zagadnienie: „Nowa wizja globalizacji: Problem demograficzny i rodzina” podjął przewodniczący Papieskiej Rady kard. A. Lopez Trujillo (s. 321-335). Dobrze, że wskazano także temat: „Rodzina na 
forum międzynarodowym" przedstawiony przez M. Schooyans (s. 337-350). Współczesność wyraźnie wskazuje, że nie można być obojętnym wobec wielorakich procesów cywilizacyjnych i stąd zapewne kwestię: „Rodzina wobec globalizacji holistycznej" podjął autor poprzedniego opracowania (s. 351-363). Dobrze, że uwypuklono zagadnienie: „Sytuacje i perspektywy wobec populacji światowej” przedstawione przez G.-F. Daumont (s. 365-376). Całość tej części zamykają spostrzeżenia wokół tematu: „Polityki ludnościowe i ich przesłanki. Przemyślenie niektórych polityk planowania rodziny”, które omówił M. Schooyans (s. 377-391).

"Rodzina i kwestie etyczne” to tematyka twórczo podjęta w szóstej części prezentowanego zbioru (s. 393-587). Otwiera go analiza kwestii: „Rodzina i bioetyka" przygotowana przez wybitnego znawcę tej problematyki E. Sgreccia (s. 395-407). Z kolei F. B. Gomez ukazał temat: „Bioetyka, rodzina chrześcijańska i życie ludzkie” (s. 409-418). Nie dziwi zatem podjęcie zagadnienia: „Lekarz cnotliwy" przeanalizowany przez F. B. Gomez (s. 419-438).

W ramach tej części skoncentrowano się bliżej na klasycznych kwestach bioetycznych. Blok ten rozpoczyna temat: „Godność embrionu ludzkiego" podjęty przez A. Serra (s. 439-444). „Status embrionu: znaczenie pewnej debaty" podjął następnie F. C. Fernandez (s. 445-460). Aborcją zainteresował się J. Suaudeau (s. 461-485), zaś eutanazji poświęcił swe przemyślenia I. Carrasco de Paula (s. 487-494). Problem: „Zabijać i pozwalać umrzeć: Jaka jest tutaj różnica?" podjął F. B. Gomez (s. 495-506). Natomiast kolejny temat został sformułowany: „Diagnostyka prenatalna” i omówił go E. Sgreccia (s. 507-517). Ostatnie zagadnienie tej części nosi tytuł: „Klonowanie” i zaprezentował je w obszernym artykule J. Stuaudeau (s. 519-587).

Całość książki zamyka obszerny spis treści, który jest dobrym i zarazem syntetycznym wprowadzeniem w całość podjętej tematyki. Ułatwia on wstępną orientację odnośnie do zawartości tak obszernego dzieła.

Prezentowana rozprawa jest pierwszym $\mathrm{z}$ trzech tomów, będących owocem specjalnych kursów organizowanych od ponad dziesięciu lat przez Papieską Radę ds. Rodziny dla biskupów w różnych częściach świata (por. s. 5). Zostały one zapoczątkowane kursem we Frascati i trwały w dniach 24.01-12.02.1994 r. Ta idea z czasem znacznie się umocniła i rozwinęła, wydając owoce, szczególnie ważne dla właściwego rozumienia duszpasterstwa rodzin. Zatem w planach wydawniczych Rady są dalsze dwa tomy wokół tej samej problematyki.

Szczególnym ubogaceniem doktrynalnym prezentowanej tematyki jest nauczanie etyczno-moralne i społeczne Jana Pawła II. Jawi się on wręcz jako niestrudzony w tym względzie, mimo tak wielkiego niezrozumienia, krytyki, a nawet pewnych wątpliwości w samym Kościele. W całym nauczaniu oraz 
świadectwie życia nieustannie trwał przy tej problematyce, a jednocześnie wskazywał na jej rangę i duszpasterskie znacznie. Pytanie dotyczy fundamentów, tj. papieskiego nauczania, które wypływa m.in. z Familiaris consortio, Gratissimam sane, Evangelium vitae, Veritatis Splendor i Katechizmu Kościoła Katolickiego. To są najważniejsze i najbardziej twórcze dokumenty w podejmowanych tutaj materiach antropologicznych oraz filozoficzno-teologicznych implikacjach małżeństwa i rodziny. $Z$ pewnością jeszcze długo pozostanie aktualnym zadanie jeszcze głębszego wniknięcia w te dokumenty.

Zasadniczymi tematami podjętymi $\mathrm{w}$ prezentowanym tomie są kwestie małżeństwa i rodziny, zawsze widziane w odniesieniu do osobowego charakteru człowieka oraz jego wymiaru społecznego, czy bardziej wspólnotowego. Chodzi tutaj jeszcze bardziej o „communio personarum”, co Jan Paweł II już wyraźnie głosił jako kard. K. Wojtyła. W tę prawdę wpisuje się twórczo małżeństwo i rodzina. Nie można jednak w ich kontekście abstrahować także od kontekstu kulturowego, społecznego, prawnego, czy nawet politycznego. Te dwie społeczności stają zawsze w swym szerokim dynamizmie, a jednocześnie same w sobie nie są obojętne.

Analizując zagadnienia małżeństwa i rodziny, należy zawsze pamiętać o licznych pozytywnych osiągnięciach współczesnych nauk, a zwłaszcza szeroko rozumianej antropologii. Kwestie te bowiem nie są obojętne dla samej teologii oraz szeroko pojętej kategorii wiary. Naturalnie, że w posłudze Kościoła wszystko to wpisane jest w posługę duszpasterską, w odpowiedzialność ewangelizacyjną, która współcześnie przybiera znamiona nowej ewangelizacji, jak to mocno i szczególnie wytrwale - od początku swego pontyfikatu - wskazywał Ojciec św. Jan Paweł II.

Zakreślony w tytule książki temat wyraźnie wskazuje na generalne linie podjętej tematyki badawczej. Koncentracja wokół rodziny nie jest jednocześnie sterylnie oddzielona od kwestii małżeńskich, choć może jest to w jakimś sensie i zamiarem autorów. Jednak dotykanie kwestii etycznych, ze swej natury, nie może pominąć sakramentalności małżeństwa i jego relacji do rodziny na nim opartej.

W wielu miejscach ważnym dopowiedzeniem jest szerokie odwoływanie się do nauczania kościelnego, tak w samym tekście, jak i w przypisach, czasem nawet dość obszernych. To bezpośrednie czy pośrednie sięganie, zwłaszcza do nauczania Jana Pawła II, stanowi pewną gwarancję wobec nauczania Kościoła, $\mathrm{z}$ jednoczesnym dostrzeganiem jego rozwoju i zarazem wrażliwości na wielość przemian społecznych i kulturowych.

Praca jest niezwykle źródłowym zbiorem szczegółowych studiów, których autorami są światowej sławy autorytety w poszczególnych dziedzinach. Zatem analiza poszczególnych kwestii jest niezwykle kompetentna i twórcza zarazem. 
Obok wymiaru naukowego jest to bardzo odpowiedzialne dotykanie niekiedy bardzo trudnych, wręcz dramatycznych współczesnych zagadnień takich, jak: aborcja, eutanazja, czy klonowanie.

Bp Andrzej F. Dziuba 